Article

\title{
Lobbying Brexit Negotiations: Who Lobbies Michel Barnier?
}

\author{
David Coen ${ }^{1, *}$ and Alexander Katsaitis ${ }^{2}$ \\ ${ }^{1}$ Department of Political Science, University College London, London, WC1H 9QH, UK; E-Mail: d.coen@ucl.ac.uk \\ 2 Department of Government, London School of Economics and Political Science, London, WC2A 2AE, UK; \\ E-Mail: a.katsaitis@Ise.ac.uk \\ * Corresponding author
}

Submitted: 16 September 2020 | Accepted: 12 December 2020 | Published: 27 January 2021

\begin{abstract}
Interest groups have a vital role in international negotiations and carry the potential to influence their outcome. This article contributes to discussions surrounding Brexit and institutional change in the EU, focusing on Article 50 negotiations and stakeholder engagement. Drawing from theories on deliberative democracy and institutional legitimacy, we argue that different groups are given access to the Chief Negotiator depending on the resources they can contribute. Assessing our expectations, we inspect the entire interest group population that held meetings with Michel Barnier and his team from 2016 onwards. On the aggregate, we observe a pluralist approach. A closer inspection reveals a tightly knit circle of insiders that hold unparalleled access. To the extent that these meetings offer a glance into the future of EU lobbying, European trade and professional associations are likely to observe growing cohesion and significance. Conversely, UK private interests will see their presence and influence diluted as their relevance grows smaller in Brussels. Following the trends we observe, think tanks and socioeconomic interests are likely to experience a continuous surge in their involvement in stakeholder activities.
\end{abstract}

\section{Keywords}

Article 50; Brexit; European Union; interest groups; lobbying; pluralism

\section{Issue}

This article is part of the issue "What Brexit Means for Europe: EU Institutions and Actors after the British Referendum," edited by Edoardo Bressanelli (Sant'Anna School of Advanced Studies, Italy) and Nicola Chelotti (Loughborough University London, UK).

(C) 2021 by the authors; licensee Cogitatio (Lisbon, Portugal). This article is licensed under a Creative Commons Attribution 4.0 International License (CC BY).

\section{Introduction}

Negotiations between the EU and the UK about the latter's withdrawal from the block, resemble a high-politics international affair (see Leruth, Gänzle, \& Trondal, 2019; Rosamond, 2016; Schimmelfennig, 2018). Interest groups have a vital role in international negotiations and carry the potential to influence Brexit's outcome. They act as a legitimizing force, a source of information and public opinion, and as a pressure mechanism on both parties (see Hurd, 1999; Walker, 1991). However, there has been limited analysis of interest group representation in Brexit negotiations. Existing work focuses on economic actors in specific sectors such as finance (Bulmer
\& Quaglia, 2018; James \& Quaglia, 2018; Lavery, 2017); but misses systematically analysing stakeholder activity in formal procedures at the EU level (Burns, Gravey, Jordan, \& Zito, 2019).

Somewhat surprisingly, even less attention is placed on the interaction between the EU's Chief Negotiator (CN) and interest groups, despite the former's commitment to stakeholder outreach (European Commission, 2016). By doing so, the literature ignores one of the most central and impactful players in Brexit negotiations; it treats a formal space where the $\mathrm{CN}$ and interest groups meet as a black-box and leaves questions about Article 50 negotiations and the future of stakeholder engagement in the EU unanswered. 
In this article, we assess the meetings between interest groups and the EU's CN, as an understudied area of Brexit. Whereas numerous groups are interested in meeting with the $\mathrm{CN}$, only a select few are able to. This generates three interconnected questions: Which groups meet with the EU's CN? Why do some groups meet more often than others? Does this carry implications for stakeholder mobilization after the UK's departure?

We answer these questions arguing that the EU's CN and the Task Force he leads have a complex role. They must convince the other side to move as close as possible to their position, while at the same time coordinate with numerous actors who operate across levels of government (Eising, 2004; Marks, Hooghe, \& Blank, 1996). The task is highly political in the sense that both negotiators emphasize normative ethical and ideological positions to justify and motivate actions, effectively framing the process as a zero-sum game (see Barley \& Kunda, 1992; Patzer, Voegtlin, \& Scherer, 2018).

Through these formal meetings the $\mathrm{CN}$ employs interest groups to explore, legitimate, and disseminate his position. Significantly, these meetings have three capacity building functions impacting which actors are invited. First, they serve a bridge-building role, offering a closed setting where central interests can exchange opinions and reach compromise (Dryzek \& List, 2003; Eriksen, 2018; Goodin, 2008), favouring economic interests. Second, these meetings act as a depolarizing chamber allowing third party perspectives to enter the negotiating space and provide value consensus (see Estlund, 2009; Landemore, 2012; Naurin, 2007), favouring epistemic interests. Third, they are used to maximize the CN's democratic credentials through groups representing public constituencies (March \& Olsen, 1984; Wood, 2015), favouring civil society organizations.

We highlight that despite the pluralist image of diverse participants, a smaller elite inner circle is likely to hold disproportionate access (Coen, Lehmann, \& Katsaitis, 2020). We assess our argument drawing on the CN's online database that includes all meetings held with organized interests (2016-2020). We map the entire population and examine which specific organizations met with Michel Barnier and his team. The results provide a nuanced perspective into interest groups involvement in the negotiations. Trade and professional associations, companies, think tanks, and NGOs are present in meetings. However, the distribution changes when we consider how often specific groups held meetings with the CN's team: EU level think tanks and associations, along with UK NGOs hold notable presence.

This article contributes to discussions specifically about interest group involvement in Brexit negotiations, and the broader literature on stakeholder engagement in EU consultation procedures. Empirically, the article conducts a unique analysis mapping the organizations meeting with Michel Barnier's team. It provides a unique dataset with 159 participants, representing 113 interest groups. Complementing discussions on formal EU consul- tations, we find that some groups are overrepresented (see, for example, Coen \& Katsaitis, 2019a; Dür \& Matteo, 2016; Fraussen, Albareda, \& Braun, 2020; Rasmussen \& Gross, 2015).

In doing so, we provide data that permits further research on Brexit, consultations, and stakeholder activity; relevant to researchers and policymakers. Overall, we address a key issue in Brexit research namely who are the key organized interests involved during the negotiations, and what implications does this carry. The pluralist nature that permeates EU intermediation is present and is likely to be maintained. However, peak level associations will be further strengthened, and UK economic interests will see a smaller presence. The article proceeds with a theoretical section that provides our central argument and expectations, followed by a section on the research design, which is proceeded by the analysis and finally a discussion on the implications.

\section{Meeting Michel Barnier: A Theoretical Appraisal}

Michel Barnier, the $\mathrm{CN}$, leads the Task Force that:

Coordinates all the Commission's work on all strategic, operational, legal and financial issues related to the UK's withdrawal from the European Union, in full respect of European Council guidelines. This includes the negotiations on the future relationship with the UK, the implementation of the Withdrawal Agreement, as well as the Commission's 'no-deal' preparedness work. (European Commission, 2016)

We assert that the EU's CN and his team aim to manage their central responsibilities in a legitimate and successful way. The motivation behind this aim can be linked to the CN's individual mandate as a member of the Commission (see Egeberg \& Trondal, 2018), as well as a rational-institutional interest to maintain and expand his authority (Dunleavy, 2014; Scharpf, 1999). Because the negotiations are framed as a zero-sum (redistributive) game, the $\mathrm{CN}$ must convince the UK side to move closer to the EU's position. Failure to do so potentially carries irreversible ramifications for EU integration (see Leruth et al., 2019), and in turn can have adverse implications for the $\mathrm{CN}$ and the Commission's authority. That is to say, a negative outcome for the EU and/or a dishonest negotiating strategy would make the Commission appear less legitimate, reducing its relevance. A central implication behind this assertion is that the $\mathrm{CN}$ does not consider illegitimate negotiating methods, such as discrediting campaigns or reneging signed agreements, as an option.

To achieve his aim, the $\mathrm{CN}$ employs different tools from the negotiation toolbox, this includes interest group engagement (see Hurd, 1999; Walker, 1991). As noted earlier, interest groups are only but a tool within a broad toolbox that carries different options. Stakeholder engagement allows the negotiator to estab- 
lish a more dominant position vis-à-vis his counterpart, primarily the UK's negotiating team, in a few ways.

By appearing as a well-accepted representative of central and/or relevant interests the $\mathrm{CN}$ holds greater political authority, i.e., she/he has comparatively greater relevance as a representative, translating into great legitimacy to speak for interests over specific issues (Zurn, Binder, \& Ecker-Ehrhardt, 2012). In a setting where issues are transnational, and constituencies do not necessarily belong explicitly to the UK's or the EU's political sphere but cut across them, the negotiator's broad acceptance (political authority) is a valuable currency. Put simply, greater relevance to constituencies acts as an informal vote, which allows one negotiating team to exert greater pressure on to the other.

Through co-ordination a negotiator can steer interest groups to apply pressure on her/his counterpart. This indirect pressure can be informal for example through unofficial meetings, and/or formal for example through open statements or members' campaigning. In doing so, the $\mathrm{CN}$ essentially attempts to support advocacy coalitions that exert pressure on the UK team. The broader and/or more relevant the coalition the greater the pressure and the ability to coerce the counterpart closer to the CN's position (Cairney, 2015; Sabatier, 1998).

Stakeholder engagement formalizes a type of information-exchange. Whereas interest groups and the $\mathrm{CN}$ may engage informally or indirectly and exchange information on issues related to Article 50, this does not necessitate that all information is available through these channels. The meeting's formality not only contributes to legitimizing factors mentioned above, but also in itself provides knowledge that improves the CN's and his team's understanding (see Russo \& Tencati, 2009).

Interest groups come in different shapes and sizes. Even under the strictest definition, which in the EU context would be an accredited lobbyist (see Coen \& Katsaitis, 2019b, for a discussion), the groups mobilized in Brussels number in the thousands. To become a legitimate representative across a plethora of interests that hold different positions across issues, operating across levels and national boundaries is a daunting task. Facing limited resources, the $\mathrm{CN}$ and his team can meet only a few. We underscore two key points that form a central frame around the article's thesis.

First, deliberative procedures, such as meetings between the $\mathrm{CN}$ and stakeholders, hold transformative, depolarizing, and coordinative properties (see Dryzek, 1990; Eriksen, 2018) that aid the CN demonstrate his relevance as well as select with which groups to meet. We highlight that these meetings are formal, noted on public record. Second, different types of interest groups bring different qualities to the discussion linked to factors such as their organizational incentives, their principals, and the constituencies they represent (Streeck \& Schmitter, 1991; Zurn et al., 2012). Below we expand on this logic, outlining our expectations regarding which types of groups the $\mathrm{CN}$ meets and why.
To begin with, deliberative procedures have a collaborative and coordinative character that allows actors to exchange opinions and reach agreement. By holding meetings with peak socioeconomic interests, such as professional and trade associations, business associations, and trade unions, the $\mathrm{CN}$ can establish a common position that includes central interests' perspectives vis-à-vis Brexit. Simultaneously, in doing so the $\mathrm{CN}$ is inclusive of and open to the most populous group mobilized in Brussels broadly categorized as private or economic interests. These groups face strong mobilization endogenously as their members scramble in anticipation of Brexit to gain valuable information and attempt to influence its outcome.

Nevertheless, Brexit's high-stakes political character invokes the use of normative ethical and moral arguments to justify the negotiators' motivation and actions (Ditto, Pizarro, \& Tannenbaum, 2009; Rosati, 1996). This can cause problems in reaching common points of agreement both endogenously as well as exogenously (Martill \& Staiger, 2020). Normative positions can be open ended and opposing, leading to polarization and sincere difficulty in obtaining common value positions (see Estlund, 2009). In a polarized environment, deliberative procedures can lead to group think and policy blindspots and/or policy gridlock (Sunstein \& Hastie, 2015; Whyte, 1998).

Research organizations such as think tanks and universities provide epistemic justification establishing the scientific method as a common ground for different ethical standpoints, de-polarizing deliberation (Dunlop \& Radaelli, 2013; Holst \& Molander, 2019). Furthermore, due to their research capacity, they are likelier to have taken normative counter arguments into consideration, their relevance and reputation is linked directly with their ability to contemplate contrasting perspectives. This allows the $\mathrm{CN}$ to form alliances with broader interest group networks, and set-up conceptual-technical safe spots within which to negotiate with the UK team. Thus, we expect to see research organizations invited to meetings with the $\mathrm{CN}$.

Stakeholder engagement is also used to broaden citizen participation in policymaking (March \& Olsen, 1984). The objective is dual. By involving organized interests representing social/public interests such as civil society and NGOs, policymakers respond to an innate critique of EU policymaking procedures being elite and exclusionary (see Schmidt, 2020). Civil society involvement allows policymakers to bolster their democratic credentials (Katsaitis, 2015). In the same way, public participation in deliberative events linked to policymaking tends to manage expectations and improve outcomes' public appreciation (Lee \& Romano, 2013; Wood, 2015). We note that while these socioeconomic interests represent numerous organizations, large scale transnational companies will receive similar attention, i.e., European champions. Because the $\mathrm{CN}$ represents the EU, EU level associations are likelier to be invited than national associations. 
In addition, by inviting interest groups from national constituencies the $\mathrm{CN}$ attempts to maintain his legitimacy vis-à-vis member states' public opinion. This factor is a concern for the Commission and becomes especially relevant when considering the potential impact of the UK's departure on the Commission's future authority. Thus, some national interests remain relevant either due to economy-size related factors (Hall \& Soskice, 2003; Thelen, 2012), as well as issue specific factors (Bulmer \& Quaglia, 2018). Therefore, trade and professional associations, companies, and business associations from central EU economies are likelier to be present, such as from Germany, France, and the UK (Eising, 2004). Moreover, to reduce the UK negotiator's political authority, the CN may welcome UK based civil society groups. Signalling to the UK team that the EU's CN also represents part of the UK's public interest, i.e., the UK team does not represent a cohesive public constituency. Focusing on constituency specific factors some social interests might observe greater participation due to issue salience for example, civil society groups from Northern Ireland.

The above dimensions frame our expectations regarding the groups' diversity, which is to say what types of groups are likely to be present in meetings with the $\mathrm{CN}$ and why. We also consider that specific groups tend to participate in such meetings more often than others. From a large interest group population, the $\mathrm{CN}$ will invite a core group of interests more often than others (Binderkrantz, 2005; Broscheid \& Coen, 2003). By doing so, the $\mathrm{CN}$ legitimizes these associations through their participation, verifying their role as representatives of their members. By galvanizing support for these interests as trusted go-to groups, these organizations act as a mediating point between the $\mathrm{CN}$ and the broader population.

In summation, the $\mathrm{CN}$ and his team face a complex task. He must represent the EU in a high-politics game and convince the UK to move closer to his position. In an international negotiation such as Brexit, there are different options in the CN's toolkit. Stakeholder engagement is one of the central tools in the kit. The $\mathrm{CN}$ will meet with different organizations to legitimate his position as a representative of states and organized interests. These meetings serve three different ideal-type purposes. First, they allow the $\mathrm{CN}$ to establish common areas of agreement and support from socioeconomic interests. Second, it allows the $\mathrm{CN}$ to depolarize the discussion and ensure a common value system through research organizations participation. Third, it provides the $\mathrm{CN}$ with democratic credentials through civil society's mobilization (see Box 1).

We underscore that this article does not take deliberative procedures as panacea or as the single most important tool that the $\mathrm{CN}$ holds at his disposal, as he attempts to achieve his objectives. We recognize that deliberative procedures face their own valid limitations (Lee, 2011; Lee \& Romano, 2013), we also recognize that the negotiations hold a central institutional and intergovernmental component (Smeets \& Beach, 2020). Nevertheless, interest groups represent an important EU policymaking cog. By examining the interaction between interest groups and the $\mathrm{CN}$ we can understand which actors are insiders, the particular forum's purpose, and estimate what implications it carries for the future of stakeholder mobilization.

\section{Research Design}

To explore these expectations, we require information on which interest groups the $\mathrm{CN}$ has held meetings with. This information is published online on the European Commission's webpage dedicated to the negotiations on Article 50 between the EU and the UK (European Commission, 2016). However, this information is available in the form of a non-downloadable table that includes: the date of the meeting, the location of the meeting, the entities met, the meeting's subject(s). To the best of our knowledge, this is the first study to assess which interest groups met with Michel Barnier's team; to ensure the study's validity and reliability we chose to collect the data manually. We collected the entire dataset with published meetings from 14 October 2016 to 29 May 2020.

We note two clarifying points. First, the entities met are not categorized, i.e., they are not classified. For example, the $\mathrm{CN}$ met with representatives from Airbus, however Airbus is not classified as a specific type of organization on the list. Second, whereas meetings can have different subjects, the subject noted largely falls in one of two categories that depend on the stage of the negotiations: (i) "Meeting with the Task Force for the Preparation and Conduct of the Negotiations with the United Kingdom under Article 50 TEU," or

Box 1. Expectations of interest groups participating in meetings with the $\mathrm{CN}$.

E1: To improve his negotiating position as a representative of vital European interests the CN will invite EU level socioeconomic groups.

E2: To form a depolarized negotiating space that allows the $\mathrm{CN}$ and counterparts to establish common value positions based on which to form agreement, the $\mathrm{CN}$ will invite epistemic organizations.

E3: To manage expectations and improve public support, the $\mathrm{CN}$ will invite UK public interests to meetings, such as civil society groups. 
(ii) "Meeting with the Task Force for Relations with the United Kingdom." The meetings on the database start on 14 October 2016 and run up to date. The former meetingsubject runs from October 2016 until December 2019, and the latter from January 2020 onward.

We opted to maintain and assess the groups that met with the CN following December 2019 along with the population beforehand. Whereas the EU-UK relationship has moved to a different stage the long-term negotiations that are following do not change the CN's aims and motivations. We placed each interest group under one of nine categories based on their self-registration on the EU's Joint Transparency Register, we highlight that the $\mathrm{CN}$ and his team will meet only with groups registered on the Joint Transparency Register. In the exceptional case where an interest group was not registered, we used their self-description on their website to place them in one of the categories: (i) business association (Association des Banques et Banquiers, Luxembourg; Bundesverband der Deutschen Industrie); (ii) company (e.g., Airbus, Crédit Agricole); (iii) consultancy (e.g., Albright Stonebridge Group); (iv) NGO (e.g., International Rescue Committee); (v) public mixed entity (e.g., Conference of Peripheral Maritime Regions, Londonderry Port \& Harbour Commissioners); (vi) religious (e.g., Commission of the Episcopates of the European Union); (vii) research organization (e.g., Centre for European Policy Studies, Centre for European Reform, North West Regional College); (viii) trade and professional association (e.g., European farmers, European Fisheries Alliance); (ix) trade union (e.g., European Trade Union Confederation, Sveriges Akademikers Centralorganisation).

We also categorized groups in one of three categories based on their level of operation i.e., which level of interests they primarily represent. Interest groups can be representing: (i) EU level interests (e.g., Bureau Européen des Unions de Consommateurs); (ii) national level interests (e.g., Association des Banques et Banquiers, Luxembourg); (iii) multinational interests (e.g., ABB).
In our analysis meeting frequency is a central variable. Since the population of meetings and interests is rather small, we focused on employing descriptive analyses. We conduct a two-level analysis. First, we note how often a type of group has met with the $\mathrm{CN}$, the objective is to understand which types of groups are popular. Therefore, we evaluate the popularity of an interest group category by examining the population size relative to the meetings held. Secondarily, we are interested in assessing the specific groups that form an elite circle of insiders. Considering the limited number of meetings, we proceeded by assessing which groups met with the $\mathrm{CN}$ a minimum of two times or more. The analysis is framed by our conceptual model and complimented by articles in this thematic issue. Having said that, we appreciate the methodology's limitations and welcome further work that enriches it. For example, approaches that seek to clarify actors' motivations and causal mechanisms through interviews or additional secondary-data.

\section{Analysis}

We begin our analysis with a breakdown of the interest group population that held meetings with the $\mathrm{CN}$ and note some initial observations (Table 1). The CN held meetings with a diverse crowd of interest groups. Most of these groups belong to the private sphere: trade and professional associations, business associations, and companies represent the majority of the population and the meetings held.

In line with our expectation, this activity follows a demand-supply argument. The $\mathrm{CN}$ is responding to the large business interest community that has mobilized due to Brexit, its support is needed to maintain and expand his legitimacy as a negotiator. On the one hand, these groups wish to gather information about the negotiations' progress, influence the $\mathrm{CN}$, and concede guarantees that their business will be affected as little as possible. On the other hand, the $\mathrm{CN}$ holds meetings with economic interests to coordinate his response,

Table 1. Meetings per type of interest group, and distribution of interest group type across the population.

\begin{tabular}{lcccc}
\hline Type & $\begin{array}{c}\text { Number of } \\
\text { Meetings }\end{array}$ & $\begin{array}{c}\text { Percentage of } \\
\text { Meetings \% }\end{array}$ & $\begin{array}{c}\text { Number of } \\
\text { Organizations }\end{array}$ & $\begin{array}{r}\text { Percentage of } \\
\text { Population \% }\end{array}$ \\
\hline Research Organization & 29 & 18 & 20 & 18 \\
Trade \& Professional Association & 29 & 18 & 17 & 15 \\
Company & 28 & 18 & 23 & 20 \\
Business Association & 24 & 15 & 18 & 13 \\
NGO & 20 & 13 & 11 & 12 \\
Trade Union & 18 & 11 & 6 & 10 \\
Professional Consultancy & 6 & 4 & 4 & 5 \\
Public Mixed Entity & 4 & 3 & 1 & 4 \\
Religious & 1 & 1 & 113 & 1 \\
Total & 159 & 100 & & 100 \\
\hline
\end{tabular}


ensuring from his perspective that a central constituency is supportive.

Research organizations hold a visible position among groups that met with the $\mathrm{CN}$. This result is in line with a growing body of work that recognizes research organizations rising prominence in Brussels, specifically think tanks (Kelstrup, 2016; Monange, 2008; Sherrington, 2000). The analysis points to a discrepancy between the overall mobilized lobbying population in Brussels and think tanks access to elite political actors and procedures (Coen \& Katsaitis, 2019a). Research organizations serve a critical role as third party actors that can provide expertise, which acts as a depolarizing device that makes coordination between the $\mathrm{CN}$ and business interests easier. This is not to say that meetings with research organizations necessarily influence the $\mathrm{CN}$ directly. Research organizations, such as think tanks, provide a common and acceptable technical basis upon which the $\mathrm{CN}$ and his counterparts can negotiate, minimizing polarized rhetoric's adverse effects (see Missiroli \& loannides, 2012).

In contrast, on the aggregate, public interest groups (e.g., NGOs) and socioeconomic interests (e.g., trade unions), represent a smaller proportion of the population. From a bird's eye view, it appears that grassroots movements are neither core legitimizing forces nor is their role as pressure mechanisms central to the $\mathrm{CN}$. With this observation, we wish to highlight the variation within categories (see Table 1), and the role of insiders. We discuss this issue in greater detail in the paragraphs that follow.

Moving from the type of groups meeting with the $\mathrm{CN}$ we also assess the level of interests they represent (see Figure 1). The $\mathrm{CN}$ has held meetings with a considerable number of organizations representing primarily national interests (35\%). However, EU level interests remain the majority $(45 \%)$, multinational interests represent a smaller proportion (20\%). We highlight that most groups representing EU groups and multinational level interests have a dedicated government affairs office in Brussels (see Figure 2). The remaining groups have an office primarily in Europe and specifically in the UK, France, or Germany. That is to say, the $\mathrm{CN}$ focuses on meeting with interest groups across levels rather than explicitly EU level groups, underscoring that his strategic concern and relevance also runs through national capitals.

As mentioned earlier, the aggregate analysis tends to support the understanding of Brexit as a trade negotiation that automatically gives economic interests a seat at the head of the table. However, a closer inspection (see Table 1), suggests that some specific groups meet with the $\mathrm{CN}$ more often than others. To better explore which groups meet more often with the $\mathrm{CN}$, we raise the minimum number of meetings held per group to two. In other words, we focus on a smaller circle that has greater access to the $\mathrm{CN}$. The image changes substantively (see Figure 3), please note that research organizations are reclassified as 'think tank' because all research organizations at this stage are think tanks. Out of a total 113 different interest groups, there is a limited 25 that have met with the $\mathrm{CN}$ more than once (mean number of meetings, 2.84 ). Indicatively, these 25 groups cover approximately $45 \%$ of all meetings. While the role of trade and professional associations becomes more evident, the analysis underscores think tanks involvement. Whereas the CN is responding to economic interests by holding multiple meetings with them, some groups offer more in terms of their ability to coordinate, depolarize, and publicly legitimize the $\mathrm{CN}$.

Following from this, we were interested in unveiling the elite circle of insiders that met with the CN often. Along these lines, we added a stronger filter on the population focusing on groups that held a number of meetings above the mean of 2.84 , i.e., groups that met with the $\mathrm{CN}$ three times or more. We assess these elite interest groups qualitatively (see Figure 4); three points become apparent.

First, EU level as well as national level interest groups maintain an important role for the CN's negotiating strategy. Legitimation and strategic use of interest groups as

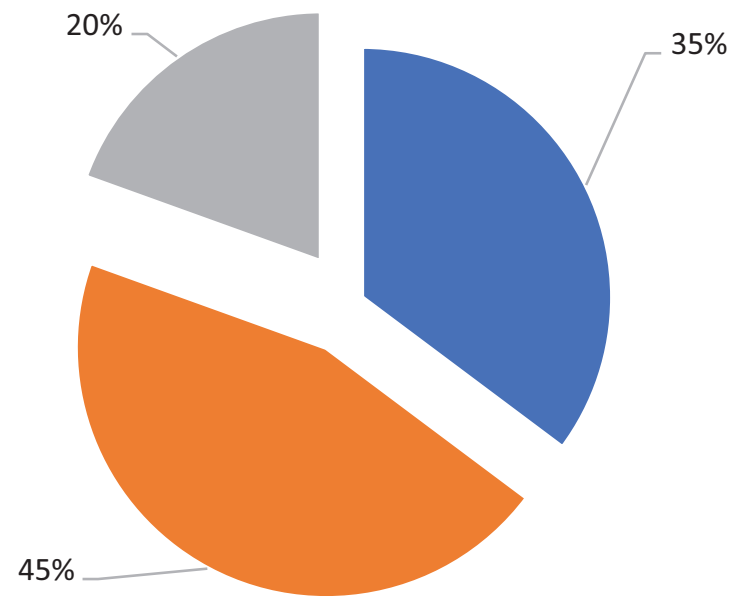

- Group Representing Primarily National Interests

- Group Representing Primarily EU Interests

- Group Representing Primarily Multinational Interests

Figure 1. Interest groups representing national, EU, or multinational interests. 


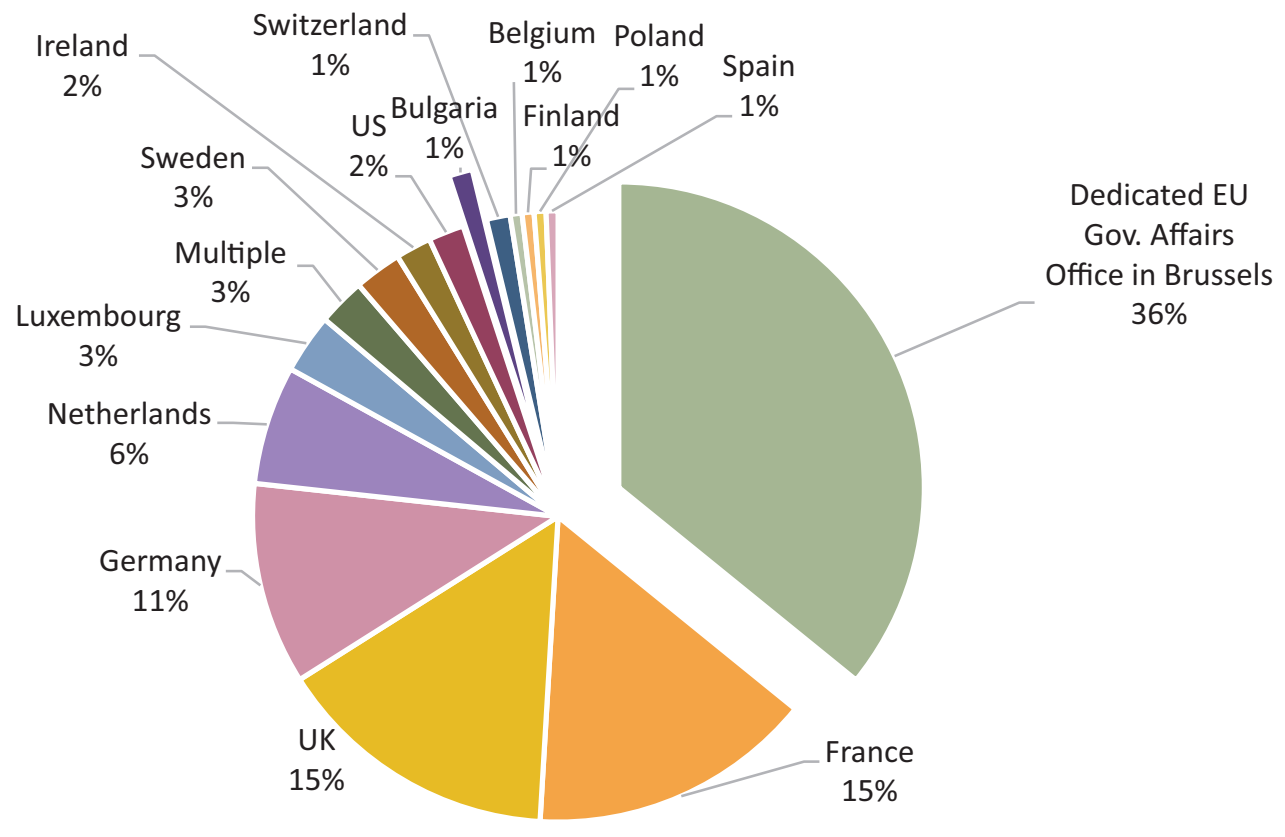

Figure 2. Interest groups government affairs' office stated location.

a pressure mechanism cuts across levels. Nevertheless, the image is intricate. UK companies and private interests more broadly have limited presence in this elite circle; however, UK trade unions and UK NGOs are welcome. This supports our expectation that UK public interests act as a tool through which the $\mathrm{CN}$ can pressure the UK team. In addition, it suggests that UK economic interests have opted for a different route of communication and coordination with the $\mathrm{CN}$ : the European level association. Overall, trade unions have an elevated role, providing further support to the argument that interest groups serve as a social coercion mechanism. Simultaneously, while think tanks participate in meetings, at the elite level they represent exclusively EU level organizations, the same applies to trade and professional associations (see COPA, COGECA, EUFA in Figure 4).

The insiders' list reflects central policy issues the negotiations focused on. Indicatively, farming and fisheries with distinct (re)distributive and political concerns as well as mobility and employment issues, require the $\mathrm{CN}$ coordinates extensively with relevant interest groups. Similarly, transnational business actors represented through the European Round Table for Industry (and BusinessEurope) are highly visible. Airbus, the EU company-project that sees airplane parts constructed across different European countries, including the UK, before being assembled in specific locations, has naturally been concerned about Brexit's impact on its future.

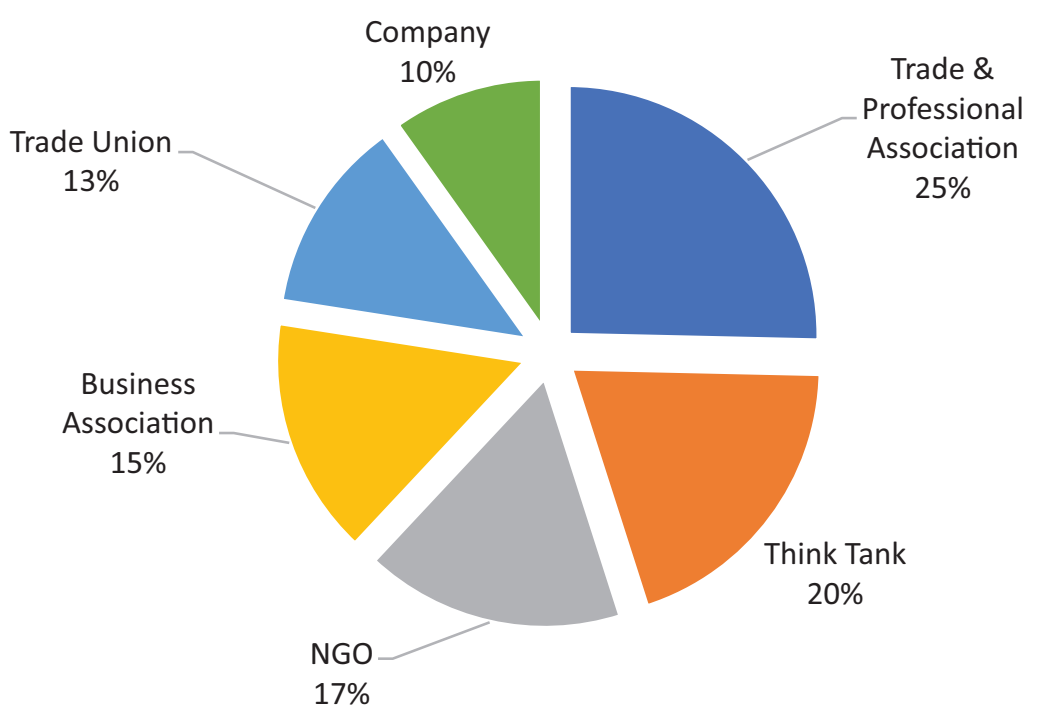

Figure 3. Percentage meetings per type of interest groups, two meetings minimum. 
Vereniging VNO-NCW (VNO-NCW)

Trades Union Congress (UK) (TUC)

the3million ( $\mathrm{t} 3 \mathrm{~m})$

Institut Jacques Delors / Jacques Delors Institute (IJD / JDI)

European Round Table for Industry (ERT)

European farmers (COPA)

European agri-cooperatives (COGECA)

Centre for European Reform (CER)

British in Europe (BiE)

European Policy Centre (EPC)

European Fisheries Alliance (EUFA)

Airbus

European Trade Union Confederation
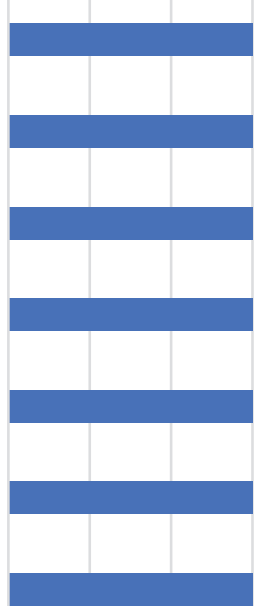

Airbus
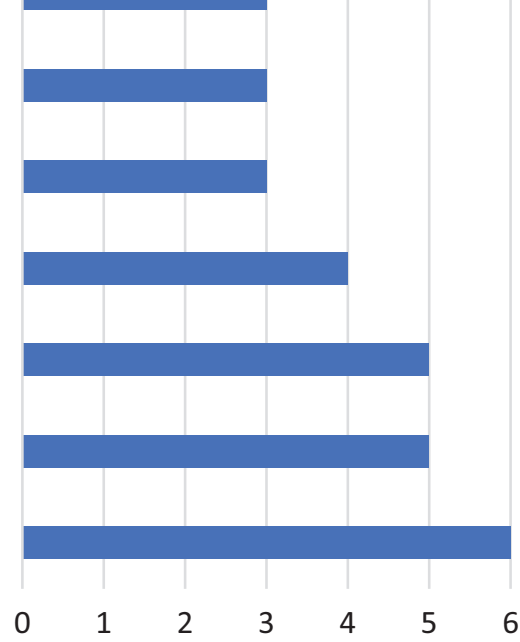

7

Figure 4. Number of meetings per organization, 3 meetings minimum.

Leading to necessary meetings to coordinate (or avoid) a multi-billion divorce. That is to say, we observe the nature of the policy field and issue salience as additional variables influencing whom the $\mathrm{CN}$ meets more often. This falls in line with a growing body of work highlighting the Commission's reaction to public opinion, and what can be more broadly termed as 'politicization' (De Wilde $\&$ Rauh, 2019). These results offer valuable information about Michel Barnier's stakeholder engagement and its purpose. Moreover, they offer a glance into EU interest intermediation after the UK's departure, which we discuss in the final section below.

\section{Discussion and Conclusions}

In support of stakeholder engagement, the EU's CN and his T50 team meet with interest groups. This article's aim was to assess which groups meet with the $\mathrm{CN}$, why do some groups meet with the $\mathrm{CN}$ more often than others, and to estimate a future trajectory of stakeholder mobilization in the EU after the UK's departure. With this in mind, we argued that the $\mathrm{CN}$ has an incentive to meet different types of groups, each organizational type offers a resource that can improve the CN's negotiat- ing position. Nevertheless, it is likely that the $\mathrm{CN}$ and his team will show greater preference towards some organizations over others. Following a formulation of expectations, we examined the entire interest group population that met with the CN from October 2016 until May 2020.

The analyses largely support our expectations. Employing these meetings to legitimize his position in a high-politics game, the $\mathrm{CN}$ meets with central socioeconomic actors that can act as a coercion mechanism, and research organizations that can provide a common technical basis that depolarizes the debate, allowing the negotiations to move forward. Significantly, the results confirm that not all groups are created equal. Highlighting the meetings exclusivity, the last four years 113 groups met with the $\mathrm{CN}$. This contrasts the large interest group populations mobilized and examined by the literature, whether they are in Brussels, registered on the Joint Transparency Register and have an accreditation. To the best of our knowledge, these meetings are some of the most elite (formal) deliberative procedures in Brussels at the moment. The specific groups meeting the most with the $\mathrm{CN}$ belong to the elite of the elite.

Considering the type of interest intermediation, the current picture resembles the EU's format with a twist. 
We observe a pluralist approach with a diverse constellation of interest group types. Looking at all the interest groups active in the consultation, we continue to see a form of EU elite pluralism where trade and professional associations and companies take up a significant portion of the meetings (Coen, 1997). These groups are de facto a larger part of the interest group population, they have a greater direct incentive to mobilize, and the resources to do so. Moreover, due to networks established over time, their access to such elite stakeholder events is likelier. Surprisingly, research organizations and think tanks also hold a prominent role, as these organizations have a growing importance within Brussels' policy circuit: We call for further research assessing their role in EU policymaking. At the same time, it indicates a distinct need for epistemic expertise that goes beyond traditional socioeconomic players and grassroots organizations.

Unsurprisingly, EU level interests receive primary attention however, national interests are also present. Indicating that the $\mathrm{CN}$ must engage with groups across levels to legitimize his role, and to create a multilevel coalition to improve the EU's negotiating position. Nevertheless, when we observe the insiders' circle research organizations, trade and professional associations are distinctly from the EU level, while trade unions, NGOs, and business associations represent a mix. On the surface this distribution suggests that little has changed and is likely to change in EU-considering interest group interactions vis-à-vis Brexit. Nonetheless, when we drill down to the specific groups meeting with the $\mathrm{CN}$ the most, some characteristics become clearer. First, UK companies are absent from the insiders' list in contrast to their overall presence in Brussels, and different to the position UK NGOs and trade unions hold.

Considering these results Brexit is likely to have two divergent effects on interest mobilization in Brussels. Because the EU aims to protect its (economic) interests, UK business will continue to lose access to EU policymakers. Since UK business interests need to maintain a good relationship primarily with the UK government, they may be less likely to formally request meetings with the $\mathrm{CN}$. In this difficult position, British companies' best option is to be represented in Brussels via EU level associations. Naturally, this will dilute their ability to influence outcomes as outsiders even within these organizations.

Conversely, as the UK public will have no access to political procedures in Brussels the EU will open-up its space towards UK public interests. This serves to maintain the EU's legitimacy vis-à-vis a portion of the UK's public as well as EU based nationals in the UK; these groups can be utilized as a direct social pressure mechanism in the future. At the same time, it helps manage the constituency's expectations through meetings that provide information and resources to nurture the relationship in a post-Brexit environment. Put differently, it will be harder to numb pro-EU mobilization in the UK as access to political resources will still be available through a different, yet smaller, route.
Somewhat ironically, the UK's departure, with its pluralist interest intermediation, might trigger greater plurality in stakeholder engagement in Brussels in terms of public interest participation. Simultaneously, it is likely push EU level interests closer together, socioeconomic interests have greater incentive to solidify their role as forums and public representatives. Specific policy areas might see greater mobilization by domestic interests following the UK's departure. Nonetheless, the dynamic we see here reflects broader patterns. Issues such as fisheries or agriculture will see greater interaction between the EU and EU level associations that can help coordinate and ensure a common front against UK counterparts. Simultaneously, larger EU economies and their associations will gain greater relative importance. This places specific national coalitions closer to the EU sphere and in turn makes their voices stronger within peak level associations. The implication being that some perspectives will become highlighted, how this translates into policy impact remains to be seen.

We point out that this research area is a fast-moving target that will unfold and develop over time, as additional negotiations are needed to agree on the specifics within policy fields. We call for further work assessing the mobilization of UK interest groups, their strategies, and their involvement in EU procedures following Brexit. The analysis underscores interest groups' role as social pressure and legitimizing mechanisms in political procedures. Future work that engages more closely with the mechanics of interest group impact on policy can offer valuable empirical and conceptual material, contributing further to EU interest intermediation's nuanced assessment.

\section{Acknowledgments}

The authors would like to thank two referees for their constructive comments. The article benefited from discussions with colleagues. We would especially like to thank the Academic Editors Edoardo Bressanelli and Nicola Chelotti for their helpful revisions on early drafts.

\section{Conflict of Interests}

The authors declare no conflict of interests.

\section{References}

Barley, S. R., \& Kunda, G. (1992). Design and devotion: Surges of rational and normative ideologies of control in managerial discourse. Administrative Science Quarterly, 37, 363-399.

Binderkrantz, A. (2005). Interest group strategies: Navigating between privileged access and strategies of pressure. Political Studies, 53(4), 694-715.

Broscheid, A., \& Coen, D. (2003). Insider and outsider lobbying of the European Commission: An informational model of forum politics. European Union Politics, 
4(2), 165-189.

Bulmer, S., \& Quaglia, L. (2018). The politics and economics of Brexit. Journal of European Public Policy, 25(8), 1089-1098.

Burns, C., Gravey, V., Jordan, A., \& Zito, A. (2019). De-Europeanising or disengaging? EU environmental policy and Brexit. Environmental Politics, 28(2), 271-292.

Cairney, P. (2015). Paul A. Sabatier, "An advocacy coalition framework of policy change and the role of policy-oriented learning therein." In E. Page, S. Balla, \& M. Lodge (Eds.), The Oxford handbook of classics in public policy and administration (pp. 484-497). Oxford: Oxford University Press.

Coen, D. (1997). The evolution of the large firm as a political actor in the European Union. Journal of European Public Policy, 4(1), 91-108.

Coen, D., \& Katsaitis, A. (2019a). Between cheap talk and epistocracy: The logic of interest group access in the European Parliament's committee hearings. Public Administration, 97(4), 754-769.

Coen, D., \& Katsaitis, A. (2019b). Legislative efficiency and political inclusiveness: The effect of procedures on interest group mobilization in the European Parliament. The Journal of Legislative Studies, 25(2), 278-294.

Coen, D., Lehmann, W., \& Katsaitis, A. (2020). Deliberative layering: Explaining diverse interest mobilization across the European Parliament's policy cycle. Journal of Public Affairs. https://doi.org/10.1002/pa. 2139

De Wilde, P., \& Rauh, C. (2019). Going full circle: The need for procedural perspectives on EU responsiveness. Journal of European Public Policy, 26(11), 1737-1748.

Ditto, P. H., Pizarro, D. A., \& Tannenbaum, D. (2009). Motivated moral reasoning. Psychology of Learning and Motivation, 50, 307-338.

Dryzek, J. S. (1990). Discursive democracy: Politics, policy, and political science. Cambridge University Press.

Dryzek, J. S., \& List, C. (2003). Social choice theory and deliberative democracy: A reconciliation. British Journal of Political Science, 33(1), 1-28.

Dunleavy, P. (2014). Democracy, bureaucracy and public choice: Economic approaches in political science. London: Routledge.

Dunlop, C. A., \& Radaelli, C. M. (2013). Systematising policy learning: From monolith to dimensions. Political Studies, 61(3), 599-619.

Dür, M., \& Matteo, G. (2016). Insiders versus outsiders: Interest group politics in multilevel Europe. Oxford: Oxford University Press.

Egeberg, M., \& Trondal, J. (2018). An organizational approach to public governance: Understanding and design. Oxford: Oxford University Press.

Eising, R. (2004). Multilevel governance and business interests in the European Union. Governance, 17, 211-245.
Eriksen, E. (2018). Getting to agreement: Mechanisms of deliberative decision-making. International Theory, 10(3), 374-408.

Estlund, D. (2009). Epistemic proceduralism and democratic authority. In R. Tinnevelt \& R. Geenens (Eds.), Does truth matter? (pp. 15-27). Dordrecht: Springer.

European Commission. (2016). Stakeholder outreach concerning Article 50 Negotiations with the United Kingdom. Brussels: European Commission. Retrieved from https://ec.europa.eu/info/news/stakeholderoutreach-concerning-article-50-negotiationsunited-kingdom-2017-mar-13_en

Fraussen, B., Albareda, A., \& Braun, C. (2020). Conceptualizing consultation approaches: Identifying combinations of consultation tools and analyzing their implications for stakeholder diversity. Policy Sciences, 53, $1-21$.

Goodin, R. E. (2008). Innovating democracy: Democratic theory and practice after the deliberative turn. Oxford: Oxford University Press.

Hall, P. A., \& Soskice, D. (2003). Varieties of capitalism and institutional complementarities. In R. Franzese, P. Mooslechner, \& M. Schürz (Eds.), Institutional conflicts and complementarities (pp. 43-76). Boston, MA: Springer.

Holst, C., \& Molander, A. (2019). Epistemic democracy and the role of experts. Contemporary Political Theo$r y, 18,541-561$.

Hurd, I. (1999). Legitimacy and authority in international politics. International Organization, 53(2), 379-408.

James, S., \& Quaglia, L. (2018). The Brexit negotiations and financial services: A two-level game analysis. The Political Quarterly, 89(4), 560-567.

Katsaitis, A. (2015). EU democratic deficit(s) and legitimacy: System versus sub-system level. In K. Demetriou (Ed.), The European Union in crisis (pp. 181-198). Cham: Springer.

Kelstrup, J. D. (2016). The politics of think tanks in Europe. London: Routledge.

Landemore, H. (2012). The mechanisms of collective intelligence in politics. Unpublished manuscript.

Lavery, S. (2017). 'Defend and extend': British business strategy, EU employment policy and the emerging politics of Brexit. The British Journal of Politics and International Relations, 19(4), 696-714.

Lee, C. W. (2011). Five assumptions academics make about public deliberation, and why they deserve rethinking. Journal of Public Deliberation, $7(1)$. http://doi.org/10.16997/jdd.118

Lee, C. W., \& Romano, Z. (2013). Democracy's new discipline: Public deliberation as organizational strategy. Organization Studies, 34(5/6), 733-753.

Leruth, B., Gänzle, S., \& Trondal, J. (2019). Exploring differentiated disintegration in a post-Brexit European Union. JCMS: Journal of Common Market Studies, 57(5), 1013-1030.

March, J., \& Olsen, J. (1984). The new institutionalism: Organizational factors in political life. The American 
Political Science Review, 78(3), 734-749.

Marks, G., Hooghe, L., \& Blank, K. (1996). European integration from the 1980s: State-centric v. multi-level governance. JCMS: Journal of Common Market Studies, 34(3), 341-378.

Martill, B., \& Staiger, U. (2020). Negotiating Brexit: The cultural sources of British hard bargaining. JCMS: Journal of Common Market Studies. https://doi.org/ 10.1111/jcms.13059

Missiroli, A., \& loannides, I. (2012). European think tanks and the EU (Berlaymont Paper Issue No. 2). Pittsburgh, PA: University of Pittsburgh.

Monange, B. F. (2008). Social science expertise and policymaking: Comparing US, French, and EU think tanks: Similar model different paths. PS, Political Science \& Politics, 41(4), 909.

Naurin, D. (2007). Deliberation behind closed doors: Transparency and lobbying in the European Union. Colchester: ECPR Press.

Patzer, M., Voegtlin, C., \& Scherer, A. G. (2018). The normative justification of integrative stakeholder engagement: A Habermasian view on responsible leadership. Business Ethics Quarterly, 28(3), 325-354.

Rasmussen, A., \& Gross, V. (2015). Biased access? Exploring selection to advisory committees. European Political Science Review, 7(3), 343.

Rosamond, B. (2016). Brexit and the problem of European disintegration. Journal of Contemporary European Research, 12(4), 864-871.

Rosati, C. (1996). Internalism and the good for a person. Ethics, 106(2), 297-326.

Russo, A., \& Tencati, A. (2009). Formal vs. informal CSR strategies: Evidence from Italian micro, small, medium-sized, and large firms. Journal of Business Ethics, 85(2), 339-353.

Sabatier, P. (1998). The advocacy coalition framework: Revisions and relevance for Europe. Journal of European Public Policy, 5(1), 98-130.
Scharpf, F. W. (1999). Governing in Europe: Effective and democratic? Oxford: Oxford University Press.

Schimmelfennig, F. (2018). Brexit: Differentiated disintegration in the European Union. Journal of European Public Policy, 25(8), 1154-1173.

Schmidt, V. A. (2020). Europe's crisis of legitimacy: Governing by rules and ruling by numbers in the eurozone. Oxford: Oxford University Press.

Sherrington, P. (2000). Shaping the policy agenda: Think tank activity in the European Union. Global Society, 14(2), 173-189.

Smeets, S., \& Beach, D. (2020). Intergovernmentalism and its implications: New institutional leadership in major EU reforms. Journal of European Public Policy, 27(8), 1137-1156.

Streeck, W., \& Schmitter, P. C. (1991). From national corporatism to transnational pluralism: Organized interests in the single European market. Politics \& Society, 19(2), 133-164.

Sunstein, C. R., \& Hastie, R. (2015). Wiser: Getting beyond groupthink to make groups smarter. Boston, MA: Harvard Business Review Press.

Thelen, K. (2012). Varieties of capitalism: Trajectories of liberalization and the new politics of social solidarity. Annual Review of Political Science, 15, 137-159.

Walker, J. L. (1991). Mobilizing interest groups in America: Patrons, professions, and social movements. Ann Harbor, MI: University of Michigan Press.

Whyte, G. (1998). Recasting Janis's groupthink model: The key role of collective efficacy in decision fiascoes. Organizational Behavior and Human Decision Processes, 73(2/3), 185-209.

Wood, M. (2015). Beyond accountability: Political legitimacy and delegated water governance in Australia. Public Administration, 93(4), 1012-1030.

Zurn, M., Binder, M., \& Ecker-Ehrhardt, M. (2012). International authority and its politicization. International Theory, 4(1), 69-106. https://doi.org/10.1017/ S1752971912000012

\section{About the Authors}

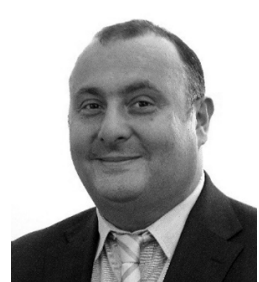

David Coen is Professor of Public Policy at the Department of Political Science, and founding Director of the Global Governance Institute at University College London. He currently holds a European Union H20/20 on Global Governance. He has published extensively in leading journals such as Journal of European Public Policy, Business \& Society, Governance, and West European Politics. Recent books include the Handbook on Business and Government (2010) OUP, Global Climate Governance (2020) CUP, and Business Lobbying in the EU (2021), OUP. https://orcid.org/0000-0001-7986-0131

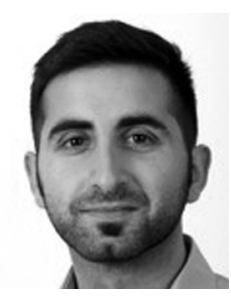

Alexander Katsaitis is Fellow in Public Policy and Administration at the London School of Economics. His research aims to improve government policymaking, specifically in the areas of governance, transparency, and representation. Previously he has been Max Weber Fellow at the European University Institute, and Postdoctoral Fellow at the ARENA Centre for European Studies at the University of Oslo. He has published in journals such as Journal of European Public Policy, Public Administration, and JCMS: Journal of Common Market Studies. https://orcid.org/0000-0002-9427-6328 